\title{
Ovulation and embryo survival rates and plasma progesterone concentrations of prolific ewes treated with PMSG
}

\author{
S. M. Rhind*, J. J. Robinson, C. Fraser and I. McHattie \\ Rowett Research Institute, Bucksburn, Aberdeen, AB2 9SB, U.K.
}

\begin{abstract}
Summary. Finnish Landrace $\times$ Dorset Horn ewes of two flocks comprising 47 and 51 animals were mated to Suffolk rams at a synchronized oestrus on 9 December (Flock D) and 8 April (Flock A) after treatment with 500 i.u. PMSG. The ewes were slaughtered between 50 and 145 days of pregnancy. The mean \pm s.e.m. ovulation rates were $4.5 \pm 0.24$ (Flock D) and $5.0 \pm 0.32$ (Flock A) for ewes which conceived to the induced oestrus and the corresponding litter sizes were $2.8 \pm 0.15$ and $2.8 \pm 0 \cdot 18$. Mean concentrations of progesterone in the peripheral plasma during pregnancy were higher for Flock $\mathrm{D}$ than for Flock $\mathrm{A}$ ewes both in early $(P<$ $0.001)$ and late $(P<0.05)$ pregnancy. An increase in ovulation rate, up to 4 or 5 , was associated with an increase in mean litter size. There was evidence that higher ovulation rates were counterproductive.
\end{abstract}

\section{Introduction}

One factor limiting production in sheep is the occurrence of a period of anoestrus lasting several months each year. Lamb production following matings within the breeding season is further limited by low ovulation rates (Hulet \& Foote, 1967) and failures of fertilization and embryonic death (Edey, 1969, 1976). Robinson, Fraser \& McHattie (1975), using a combination of treatments, including controlled photoperiod, early weaning and pregnant mares' serum gonadotrophin (PMSG) injections, successfully eliminated seasonality and maintained a high level of lamb production from Finnish Landrace $\times$ Dorset Horn ewes bred at 7-month intervals. However, reproductive performance was measured only in terms of conception rates and lambing percentages, and the factors limiting production under these conditions could not be assessed. The aim of the present work was to investigate ovulation rates, the subsequent development of embryos and fetuses and the associated changes in the concentrations of progesterone in the peripheral plasma of the ewes that were used in the studies of Robinson et al. (1975).

\section{Materials and Methods}

Two flocks of 47 and 51 mature Finnish Landrace $\times$ Dorset Horn ewes (selected from a common source), were synchronized in oestrus and mated with Suffolk rams on 9 December (Flock D) and 8 April (Flock A) respectively. Synchronization was by means of intravaginal pessaries containing $30 \mathrm{mg}$ of a synthetic progestagen (SC 9880: G. D. Searle Ltd) plus $400 \mathrm{mg}$ progesterone (Sigma Chemicals, St. Louis, Missouri, U.S.A.). Pessaries were removed after 12 days and each ewe was given an intramuscular injection of 500 i.u. PMSG (Folligon: Intervet Ltd, Bar Hill, Cambridge, U.K.). The ewes were housed in light-proof buildings and subjected to an artificial photoperiod. The 'daylength' was abruptly increased to $18 \mathrm{~h}$ during the $3 \mathrm{rd}$ month of

* Present address: Hill Farming Research Organisation, Bush Estate, Penicuik, Midlothian EH26 OPY, U.K. 
a pregnancy and reduced by $3.5 \mathrm{~min} /$ day for a 6 -month period spanning mating and the early part of the next pregnancy so that matings were under light conditions equivalent to those pertaining in December at $57^{\circ} 10^{\prime} \mathrm{N} 2^{\circ} 04^{\prime} \mathrm{W}$ irrespective of the actual time of year.

Lambs were weaned after 28 days and the ewes, which were individually penned, were then given different amounts of feed so that all achieved a uniformly good condition before mating. All ewes were fed $(2 \mathrm{~kg} /$ day) on Ruminant Diet A (Wainman, Blaxter \& Pullar, 1970) which contains $8.1 \mathrm{MJ}$ of metabolizable energy and $150 \mathrm{~g}$ crude protein $/ \mathrm{kg}$ dry matter, for at least 1 month before and 1 month after mating. During the last 2 months of pregnancy ewes were allocated feed according to fetal numbers determined by X-ray in Week 12 of pregnancy. Nutrition and management were the same for both flocks. The ewes were slaughtered between 50 and 145 days of gestation (Robinson, McDonald, Fraser \& Crofts, 1977) and the uterus was removed intact. The numbers of corpora lutea in each ewe were assessed by dissection of the ovaries. The uterus was opened by a mid-line incision of each horn and the numbers of fetuses noted. The presence of atrophied placental tissue was taken as evidence of late embryonic or early fetal death.

Blood samples were taken from each ewe by jugular venepuncture at approximately 10-day intervals until slaughter. The concentrations of progesterone in the plasma were determined by a modification of the method of Henricks, Dickey \& Hill (1971) with an antiserum (Y 29/6) raised in sheep to 6 $\beta$-hydroxyprogesterone-hemisuccinyl-BSA diluted to $1: 4000$ in phosphate-buffered saline- $0.1 \%$ gelatin. Cross-reactions were $8.8 \%$ with $5 \beta$-pregnane-3,20-dione, $11.1 \%$ with deoxycorticosterone and negligible for other steroids. Intra- and inter-assay coefficients of variation were $\pm 12 \%(n=19)$ and $\pm 22 \%(n=42)$ respectively for a sample containing $3.8 \mathrm{mg}$ progesterone $/ \mathrm{ml}$. The sensitivity of the assay was $0.04 \mathrm{ng} /$ tube. Mean recovery of $\left[{ }^{3} \mathrm{H}\right]$ progesterone for each of 4 concentrations within the range $0.5-9.5 \mathrm{ng} / \mathrm{ml}$ was $78 \pm 0.7 \%(n=12$ for each concentration).

Hormone values for ewes slaughtered before Day 60 are not included in the mean values for the first 2 months of pregnancy and similarly values for ewes slaughtered before Day 126 are not included in the mean values for late pregnancy. The mean values are therefore based on 34 ewes of each flock until Day 60 and on 18 (Flock D) and 19 (Flock A) ewes thereafter.

\section{Results}

\section{Ovulation rates and litter sizes}

All of the ewes showed behavioural oestrus after pessary withdrawal; $75 \%$ of Flock D and $73 \%$ of Flock A conceived to the induced oestrus and a further $11 \%$ and $8 \%$ of the respective flocks conceived to the first repeat oestrus.

The mean $( \pm$ s.e.m.) ovulation rates of $4.5 \pm 0.24$ and $5.0 \pm 0.32$ for Flocks $D$ and A respectively were not significantly different. The corresponding values for ewes that conceived to the repeat oestrus were lower, being $3.0 \pm 0.00(n=5)$ and $2.8 \pm 0.22(n=4)$. Ovulation rates were not related to ewe liveweight or body condition at mating.

Mean ( \pm s.e.m.) litter sizes for ewes that conceived to the induced oestrus were $2.8 \pm 0.15$ (range 1-4) and 2.8 \pm 0.18 (range 1-5) for Flocks D and A respectively. Corresponding values for those that conceived to the repeat oestrus were $1.8 \pm 0.33$ and $2.0 \pm 0.35$. As there were no significant differences in ovulation rate or litter size between the two flocks, the data were pooled for further analyses.

\section{Egg wastage}

The proportion of eggs shed that was represented by viable fetuses at the time of slaughter in all of the ewes which conceived to the induced or repeat oestrus was inversely related to 
ovulation rate (see Table 1). In many ewes the fate of the lost eggs was not clear, but some of the eggs had been successfully fertilized and death of the fetuses had occurred at a fairly late stage. A $\chi^{2}$ test showed that the incidence of detectable embryonic or fetal death was positively related $(P$ $<0.01$ ) to ovulation rate (see Table 1). Detectable losses were divided into three categories. In 10 ewes variable quantities of decaying membranes were present. The large amounts present suggest that death occurred some time after Day 25 of gestation. In another 16 ewes the cotyledonary burrs had an appearance characteristic of those which had been recently attached to a conceptus, i.e. they must have developed until at least Day 30 of gestation and often much later. One ewe slaughtered at parturition was carrying two normal fetuses and a mummified fetus, the skeletal development of which was equivalent to that of a fetus of at least 70 days of age according to the criteria of Wenham (1977).

The highest mean litter sizes were obtained with intermediate ovulation rates (see Table 1) because of the increased egg wastage with higher ovulation rates, but this was not statistically significant. Statistical validation would require very much larger numbers of ewes in the higher ovulation rate categories.

Table 1. Total egg wastage and incidence of late embryo/early fetal loss in relation to ovulation rate together with the distribution of ewes by litter size

\begin{tabular}{|c|c|c|c|c|c|c|c|c|c|}
\hline \multirow[b]{2}{*}{$\begin{array}{l}\text { Ovulation } \\
\text { rate }\end{array}$} & \multirow[b]{2}{*}{$\begin{array}{l}\text { No. of } \\
\text { ewes }\end{array}$} & \multirow{2}{*}{$\begin{array}{l}\text { Egg wastage } \\
(\%)\end{array}$} & \multirow{2}{*}{$\begin{array}{l}\text { No. of ewes with } \\
\text { late embryo or } \\
\text { early fetal loss } \\
\text { (\%) }\end{array}$} & \multirow{2}{*}{$\begin{array}{c}\text { No. of viable } \\
\text { fetuses/ewe at } \\
\text { slaughter } \\
\text { (mean } \pm \text { s.e.m.) }\end{array}$} & \multicolumn{5}{|c|}{$\begin{array}{l}\text { Distribution of ewes by } \\
\text { litter size }\end{array}$} \\
\hline & & & & & 1 & 2 & 3 & 4 & 5 \\
\hline 2 & 2 & 0 & $0(0)$ & 2.00 & 0 & 2 & & & \\
\hline 3 & 26 & 24 & $3(12)$ & $2.27 \pm 0.16$ & 5 & 9 & 12 & & \\
\hline 4 & 23 & 25 & $5(22)$ & $3.00 \pm 0.18$ & 1 & 5 & 10 & 7 & \\
\hline 5 & 12 & 30 & $5(42)$ & $3.50 \pm 0.29$ & 0 & 2 & 5 & 2 & 3 \\
\hline 6 & 8 & 60 & $5(63)$ & $2.38 \pm 0.42$ & 2 & 3 & 1 & 2 & 0 \\
\hline 7 & 2 & 57 & $2(100)$ & 3.00 & 0 & 0 & 2 & 0 & 0 \\
\hline 8 & 5 & 65 & $5(100)$ & $2.80 \pm 0.49$ & 1 & 0 & 3 & 1 & 0 \\
\hline 9 & 2 & 72 & $1(50)$ & 2.50 & 0 & 1 & 1 & 0 & 0 \\
\hline 10 & 1 & 90 & $1(100)$ & 1.00 & 1 & 0 & 0 & 0 & 0 \\
\hline
\end{tabular}

\section{Progesterone concentrations in ewe plasma during pregnancy}

The design of the experiment did not allow determination of progesterone levels of all ewes throughout an entire pregnancy. Concentrations during the first 60 days of gestation and the remaining period are considered separately since the mean site of progesterone synthesis for the first 60 days is the corpus luteum but after this the placenta becomes the principal source.

Since blood samples were collected at different days of gestation in the two flocks, direct comparisons between flocks at specific days of pregnancy were not possible. Mean concentrations of progesterone at Days 40,70 and 100 of pregnancy, for ewes bred at each season, were therefore estimated from the linear regressions of progesterone concentration on stage of gestation. Separate regressions were calculated for early, middle and late pregnancy.

Mean progesterone values at Day 40 increased with increasing ovulation rate (see Table 2) with the exception of one anomalous value. The difference between the two flocks in progesterone concentration at this time was not attributable to difference in ovulation rate, the mean rates being 5.0 (Flock D) and 4.9 (Flock $\mathrm{A}$ ) for the ewes included in these comparisons. Furthermore flock differences were recorded in the mean values for ewes in each ovulation rate category from 3 to 5 . 
S. M. Rhind et al.

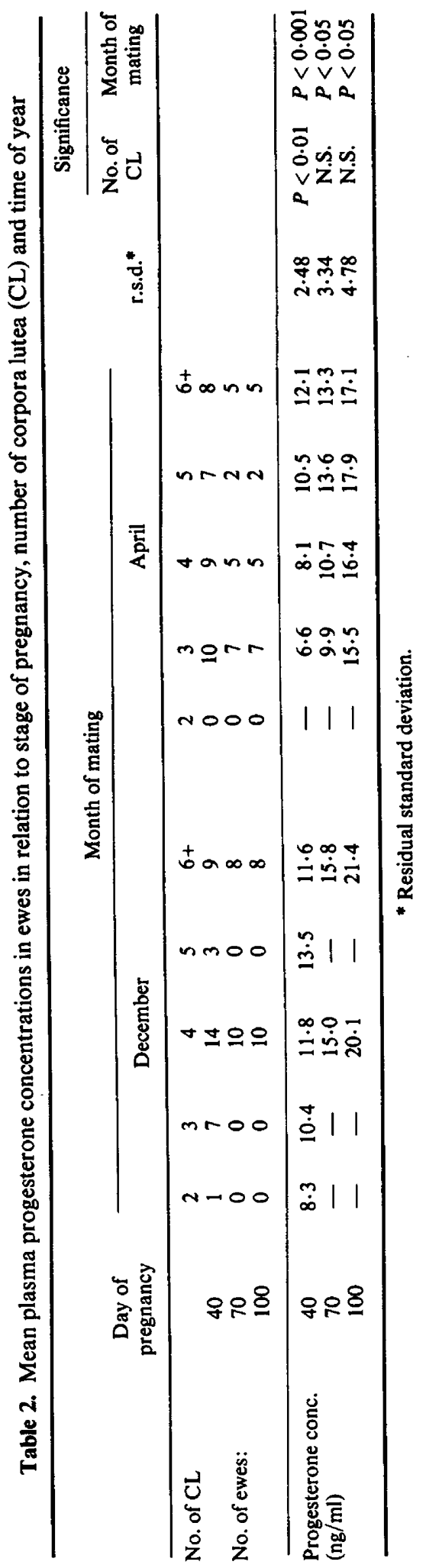


No relationship was found between ovulation rate and progesterone concentrations at 70 and 100 days of gestation when progesterone is produced mainly by the placenta.

\section{Discussion}

The differences in ovulatory response to PMSG with time of year reported by Robinson (1950) and Rhind, Robinson, Chesworth \& Phillippo (1980) contrast with the present findings. It would therefore appear that the artificial photoperiod was effective in eliminating the natural seasonal variation (Hendy \& Bowman, 1974) in ovulation rate.

The mean ovulation rates of ewes treated with PMSG in the present study were very high compared with normal values for Finn $\times$ Dorset Horn ewes which are reported to be between 2.1 and 3.1 depending on level of feed intake and lactation (Shevah, Black, Carr \& Land, 1974; Shevah, Black \& Land, 1975). Nevertheless, the finding that the mean litter size increased with increases in the numbers of ovulations, up to 5 , suggests that up to this number ovulation rate may limit litter size.

With ovulation rates of 5 or less, the proportions of eggs shed that were represented by viable fetuses were consistent with normal rates of failure of fertilization and of embryonic mortality, i.e. about 10\% (Hancock, 1962) and 20\% (Edey, 1969) respectively (see Table 1). With ovulation rates of 6 or more, however, there was a significant deviation from the expected litter size indicating an increase in egg/embryo or early fetal loss possibly due to limited uterine capacity. While there were insufficient ewes to demonstrate a significant reduction in litter size with ovulation rates of more than 5 , the decrease is consistent with trends observed by Hanrahan (1976) and Land \& Wilmut (1977), suggesting that there is an intermediate optimum ovulation rate.

Robinson (1951) and Bindon, Ch'ang \& Turner (1971) found that in ewes induced to superovulate most eggs are normally fertilized and that embryonic mortality increases with ovulation rate, a finding consistent with the present data. In their studies most of the deaths occurred during the first 3 weeks of pregnancy. In contrast, a feature of the present experiment is that many of the deaths occurred at a later stage of gestation than normal, i.e. more than 7 days after implantation; these deaths are similar in timing to those observed by Edey, Kilgour \& Bremner (1978) in ewe lambs, most of which were carrying single fetuses. The lateness of the deaths suggests that they were not attributable to abnormalities of the fetus, a common cause of early loss (Edey, 1976), but rather to physical factors such as an inadequate blood supply.

The mean progesterone concentrations of the ewes during pregnancy were very high compared with those reported for naturally bred ewes of conventional breeds (Thorburn, Bassett \& Smith, 1969; Fylling, 1970). This may be attributable in part to the high ovulation rates induced by treatment with gonadotrophin, particularly since there was a positive relationship between progesterone concentration and ovulation rate. While a similar relationship was recorded by Eastwood, Payne, Fairclough \& McDonald (1976), the mean values that they obtained for Romney ewes or crosses induced to superovulate and having up to 6 corpora lutea were much lower than for ewes in the corresponding categories in the present experiment.

While the application of an artificial daylength regimen apparently eliminated the seasonal variation in ovulation rate and litter size that occurs under natural daylength conditions, seasonal variation was still evident in the progesterone concentrations of the ewes, those mated during the normal breeding season (December) having higher concentrations than those mated during the normal period of anoestrus (April).

We thank Dr C. Munro, Glasgow Veterinary School, Bearsden, Glasgow, for gifts of progesterone antiserum. During the course of this work, S.M.R. was in receipt of an Agricultural Research Council Scholarship. 


\section{References}

Bindon, B.M., Ch'ang, T.S. \& Turner, H.N. (1971) Ovarian response to gonadotrophin by Merino ewes selected for fecundity. Aust. J. agric. Res. 22, 809820.

Eastwood, K.C., Payne, E., Fairclough, R.J. \& McDonald, M.F. (1976) Plasma progesterone concentration during pregnancy in Romney and Border Leicester $x$ Romney ewes after gonadotrophin treatment. $N . Z . J l$ agric. Res 19, 271-276.

Edey, T.N. (1969) Prenatal mortality in the sheep: a review. Anim. Breed. Abstr. 37, 173-190.

Edey, T.N. (1976) Embryo mortality. In Proc. Int. Sheep Breed. Conf., Muresk, pp. 400-410. Ed. G. J. Tomes. New England University, Armidale, Australia.

Edey, T.N., Kilgour, R. \& Bremner, K. (1978) Sexual behaviour and reproductive performance of ewe lambs at and after puberty. J. agric. Sci., Camb. 90, 83-91.

Fylling, P. (1970) The effect of pregnancy, ovariectomy and parturition on plasma progesterone level in sheep. Acta. endocr., Copenh. 65, 273-283.

Hancock, J.L. (1962) Fertilization in farm animals. Anim. Breed. Abstr. 30, 285-310.

Hanrahan, J.P. (1976) Repeatability of ovulation rate and its relationship with litter size in four sheep breeds. Proc. 27th A. Meeting, E.A.A.P., Zurich, G30, S38, pp. 1-8.

Hendy, C.R.C. \& Bowman, J.C. (1974) The association between variation in the seasonal onset of oestrus and litter size in the ewe. J. Reprod. Fert. 40, 105-112.

Henricks, D.M., Dickey, J.F. \& Hill, J.R. (1971) Plasma estrogen and progesterone levels in cows prior to and during estrus. Endocrinology 89, 1350-1355.

Hulet, C.V. \& Foote, W.C. (1967) Relationship between ovulation rate and reproductive performance in sheep. J. Anim. Sci. 26, 563-566.

Land, R.B. \& Wilmut, I. (1977) The survival of embryos transferred in large groups to sheep of breeds with different ovulation rates. Anim. Prod. 24, 183-187.

Rhind, S.M., Robinson, J.J., Chesworth, J.M. \&
Phillippo, M. (1980) Effects of season, lactation and plane of nutrition on the reproductive performance and associated plasma $\mathbf{L H}$ and progesterone profiles in hormonally treated ewes. J. Reprod. Fert. 58, 127137.

Robinson, J.J., Fraser, C. \& McHattie, I. (1975) The use of progestagens and photoperiodism in improving the reproductive rate of the ewe. Annls Biol. anim. Biochim. Biophys. 15, 345-352.

Robinson, J.J., McDonald, I., Fraser, C. \& Crofts, R.M.J. (1977) Studies on reproduction in prolific ewes. 1. Growth of the products of conception. $J$. agric. Sci., Camb. 88, 539-552.

Robinson, T.J. (1950) The control of fertility in sheep. 1. Hormonal therapy in the induction of pregnancy in the anoestrus ewe. J. agric. Sci., Camb. 40, 275-307.

Robinson, T.J. (1951) Reproduction in the ewe. Biol. Rev. 26, 121-157.

Shevah, Y., Black, W.J.M., Carr, W.R. \& Land, R.B. (1974) The effect of lactation on the resumption of reproductive activity and the preovulatory release of LH in Finn $\times$ Dorset ewes. J. Reprod. Fert. 38, 369378.

Shevah, Y., Black, W.J.M. \& Land, R.B. (1975) The effects of nutrition on the reproductive performance of Finn $\times$ Dorset ewes. II. Post-partum ovarian activity, conception and the plasma concentrations of progesterone and LH. J. Reprod. Fert. 45, 289-299.

Thorburn, G.D., Bassett, J.M. \& Smith, I.D. (1969) Progesterone concentrations in the peripheral plasma of sheep during the oestrous cycle. J. Endocr. 45, 459469.

Wainman, F.W., Błaxter, K.L. \& Pullar, J.D. (1970) The nutritive value for ruminants for a complete processed diet based on barley straw. J. agric. Sci., Camb. 74, 311-314.

Wenham, G. (1977) Studies on reproduction in prolific ewes. 2. A radiographic study of the primary and secondary ossification centres of the foetus. J. agric. Sci., Camb. 88, 553-566.

Received 20 April 1979 